\title{
Acid Angiotensinase, Renin, and Acid Adenosine Triphosphatase in Rat Kidney Lysosomes
}

\author{
Masato Matsunaga, Jun Kira, Noboru. Saito, Koichi Ogino \\ and Masao Takayasé ${ }^{\dagger}$
}

$\mathrm{L}$

ysosomes have been assigned recently an important role in many physiological and pathological processes ${ }^{1-5}$. The authors reported the presence of renin, hemoconcentrating substance, vascular permeability factor, and acid adenosine triphosphatase in lysosomal fraction of rat kidney, and emphasized possible participation of lysosomes in the pathogenesis of hypertension as well as other cardiovascular diseases $^{6-10}$. Although the renin-angiotensin system in physiological and pathological states has been thoroughly studied by many investigators, the nature of the enzymes involved in degradation of angiotensin seems to be still unestablished $^{11}$. The present study reveals that rat kidney lysosomes contain an angiotensinase which is active at an acid $\mathrm{pH}$. Further study on renin and acid adenosine triphosphatase was also carried out.

\section{Materials ANd Methods}

\section{Animals}

Closely inbred Wistar rats (Animal Center of Kyoto University) of either sex weighing 200$300 \mathrm{gm}$ were used for the source of the kidneys. Closely inbred female Sprague-Dawley rats (Japan Clea Inc., Takatsuki, Japan) weighing $200-300 \mathrm{gm}$ were used for bioassay of angiotensin.

\section{Tissue Fractionation}

Rats were killed by bleeding from the ter- minal aorta under light ether anesthesia. Kidneys were quickly removed and transferred into cold sucrose solution. Homogenization and fractionation were performed according to the method of SHIBKo and TAPPEL ${ }^{12}$ with a slight modification as described previously ${ }^{6}$. Ethylenediamine tetraacetic acid (EDTA) was not used during the procedure. Lysosomal, mitochondrial, microsomal and final supernatant fractions were prepared.

\section{Enzyme Assay}

Each fraction was frozen and thawed ten times before enzyme assay, unless otherwise stated, to disrupt the membrane of the subcellular particles. Protein concentration was determined by the mothod of Lowry et al. ${ }^{13}$, employing bovine albumin (Armour Lab) as a standard.

\section{Angiotensionase}

Valyl $l^{5}$-angiotensin II amide (Ciba) dissolved in 0.1 per cent bacitracin solution in a concentration of $0.25 \mu \mathrm{g}$ per mililiter was used as the substrate. Phosphate, tris-maleate or acetate buffer was used according to the purpose of experiments.

One $\mathrm{ml}^{2}$ of the substrate solution, $1 \mathrm{ml}$ of $0.5 \mathrm{M}$ buffer solution, and $0.1 \mathrm{ml}$ of each fraction (usually contained $0.1 \mathrm{mg}$ of protein) in a total volume of $4 \mathrm{ml}$ were incubated in a water bath at $37^{\circ} \mathrm{C}$ for 15 minutes. At the end of the incubation period tubes were transferred to iced

† The 3rd Division of Internal Medicine, School of Medicine, Kyoto University, Kyoto (Director: Prof. M.Takayasu)

(Received for Publication, December 28, 1967) 
water and $\mathrm{pH}$ was adjusted to 5.0 with $1 \mathrm{~N}$ $\mathrm{HCl}$, when a neutral $\mathrm{pH}$ had been adopted. Proteins were precipitated by placing the tubes in boiling water for 10 minutes, then centrifuged, and angiotensin in the supernatant was bioassayed. As a control, a tube of the incubation mixture without enzyme sample was treated in the same way.

2. Renin

To $0.1 \mathrm{ml}$ of a sample was added $2 \mathrm{ml}$ of rat plasma which contained $5 \mathrm{mM}$ EDTA-Na $\mathrm{Na}_{2}, 1$ $\mathrm{ml}$ of $0.01 \mathrm{M}$ EDTA $-\mathrm{Na}_{2}$ in 0.9 per cent $(\mathrm{w} / \mathrm{v})$ saline, and $0.9 \mathrm{ml}$ of saline. After incubation at $37^{\circ} \mathrm{C}$ for 10 minutes, proteins were removed by heating at $\mathrm{pH} 5.5$ as described above. Pressor substance (angiotensin) in the supernatant was bioassayed. The value from a mixture without enzyme sample was subtracted.

3. Adenosine Triphosphatase (ATPase)

Acid ATPase activity in Sephadex G-100 eluates was determined as follows. The incubation mixture which contained, in a total volume of $3.5 \mathrm{ml}, 1.9 \mathrm{mM}$ adenosine triphosphate (Sigma Co.), $2 \mathrm{ml}$ of $0.2 \mathrm{M}$ tris-acetate buffer ( $\mathrm{pH} 5.0)$ and $1 \mathrm{ml}$ of a sample, was incubated at $37^{\circ} \mathrm{C}$ for 30 minutes. Reaction was stopped by the addition of $4 \mathrm{ml}$ of cold trichloroacetic acid $(10 \% \mathrm{w} / \mathrm{v})$. Inorganic phosphorus in the filtrate was determined by the method of Allen modified by NAKam.URA ${ }^{14}$, and nonenzymatic inorganic phosphorus in the substrate was subtracted. The activity in DEAEcellulose eluates was measured in the same way, but the incubation mixture contained $2.2 \mathrm{mM}$ substrate and $0.5 \mathrm{ml}$ of the sample in a total volume of $3.0 \mathrm{ml}$. Incubation was done for 45 minutes and $5 \mathrm{ml}$ of trichloroacetic acid was added.

4. Acid Phosphatase

The methods were the same as those for ATPase, except that $43 \mathrm{mM} \beta$-glycerophosphate (Merck Co.) was used as the substrate in place of adenosine triphosphate.

\section{Bioassay of Angiotensin}

Rats were anesthetized by an intraperitoneal injection of sodium amobarbital $(100 \mathrm{mg} / \mathrm{kg})$ and given pentolinium $(4-6 \mathrm{mg} / \mathrm{kg}$ ) subcutaneously. The carotid artery was connected to a mercury manometer. A sample was injected into a femoral vein and washed through with saline so that the total volume injected was $0.3 \mathrm{ml}$. The amount of angiotensin was determined by its pressor effect as compared with a standard.

\section{Chromatography}

Lysosomal fraction, after ten-time freezing and thawing, was dialyzed against 0.9 per cent saline overnight in a refrigerator. After centrifugation at $100,000 \mathrm{G}$ for 60 minutes, the supernatant fluid was applied to the column.

\section{Sephadex G-100 Gel Filtration}

The cross-linked dextran gel (Sephadex G100, medium, Pharmacia, Uppsala, Sweden) was suspended in 0.9 per cent $(\mathrm{w} / \mathrm{v}) \mathrm{NaCl}$ solution and stirred with a magnetic stirrer during three days. After still-standing, supernatant saline which contained a small amount of very fine particles was drained off with a siphon. The same procedure was repeated until the supernatant became clear. A small amount of glass wool was placed on the outlet of a glass column with $1.53 \mathrm{~cm}$ inner diameter, and a 0.5 cm layer of swelled Sephadex G-25 Coarse on it. The column was placed vertically in a cold room and packed by gravity flow with thin slurry of swelled gel equiblirated with the room temperature $\left(4-6^{\circ} \mathrm{C}\right)$. The height of the gel bed was $39.4 \mathrm{~cm}$ and the volume of the bed, $72 \mathrm{ml}$. The sample was slowly introduced between the gel surface and the saline over it with a long needle whose tip was bent at a right angle. The elution was made under a low hydrostatic pressure to maintain a flow rate within $10 \mathrm{ml} /$ $\mathrm{hr}$. The effluent was collected in about $4.3 \mathrm{ml}$ portions in a gravimetric fraction collector (Toyo Industrial Co., SF-200A).

2. DEAE-cellulose Column Chromatography

The anion exchange cellulose column (23.3 $\times 0.91 \mathrm{~cm})$ was prepared as described by $\mathrm{PE}$ TERSON and SOBER ${ }^{15}$. The sample was applied to the column after overnight dialysis against the starting buffer $(0.05 \mathrm{M}$ tris-chloride buffer, $\mathrm{pH}$ 8.0) and allowed to soak in by gravity. Collection was started when the sample was first applied to the column. After collecting 89 fractions which were eluted with the starting buffer, linear chloride gradient was applied by the two-chamber device ${ }^{16}$. The mixing buffer 
contained $0.5 \mathrm{M} \mathrm{NaCl}$ in the starting buffer. Finally, tris-chloride buffer (0.05 M, pH 8.0) containing $1 \mathrm{M} \mathrm{NaCl}$ was applied. All of the procedures were performed in a cold room. Each fraction obtained was dialyzed against saline solution before subjected to the assays.

\section{RESUlts}

\section{Angiotensinase}

Angiotensinase activity of the four subcellular fractions at $\mathrm{pH} 5.0$ and $\mathrm{pH} 7.6$ is shown in Table I. The activity of lysosomal fraction was prominent at $\mathrm{pH} 5.0$ and negligible at $\mathrm{pH}$ 7.6, while the opposite was true in microsomal fraction. Mitochondrial and supernatant fractions had only a slight activity at $\mathrm{pH} 5.0$ and pH 7.6, respectively.

Table I Angiotensinase Activity in SubCellular Fractions

\begin{tabular}{lcc}
\hline \multirow{2}{*}{ Fraction } & \multicolumn{2}{c}{ Activity } \\
\cline { 2 - 3 } & $p H 5.0$ & $p H 7.6$ \\
\hline Lysosomal & 215 & 0 \\
Mitochondrial & 41 & 0 \\
Microsomal & 0 & 223 \\
Supernatant & 0 & 14 \\
\hline
\end{tabular}

Activity is expressed in nanograms of angiotensin inactivated by $0.1 \mathrm{mg}$ of protein, at $37^{\circ} \mathrm{C}$ for 15 minutes.

When one drop of $1: 20$ solution of di-isopropylfluolophosphate (DFP) in isopropylalcohol was added to the incubation mixture, the activity of the lysosomal enzyme was markedly inhibited while the microsomal was not affected (Table II). The latter activity was inhibited by overnight dialysis against EDTA$\mathrm{Na}_{2}$ solution $(2.2 \mathrm{~g} / \mathrm{L}$ in 1 per cent saline, adjusted to $\mathrm{pH} 7.0$ with $1 \mathrm{~N} \mathrm{NaOH}$ ), and fully restored by the addition of $5 \mathrm{mM} \mathrm{CaCl}{ }_{2}$. The same treatment hardly affected the lysosomal enzyme.

Table II Inhibition and Activation of ANGIOTENSINASES

\begin{tabular}{lcc}
\hline \multicolumn{1}{c}{ Treatment } & Lysosomal & Microsomal \\
\hline \multicolumn{1}{c}{-} & 100 & 100 \\
DFP & 13 & 99 \\
Dialysis against EDTA & 100 & 17 \\
Dialysis $+C a^{++}$ & - & 99 \\
\hline
\end{tabular}

The activity without treatment is taken as 100.

The original lysosomal fraction was frozen and thawed stepwise to ten times, put in a deep freezer and in running tap water alternatively, and centrifuged at $12,200 \mathrm{G}$ for 10 minutes. Acid angiotensinase activity in the supernatant fluid was assayed. As is seen in Fig. 1., lysosomal angiotensinase was inactive before this treatment and released from the particles by disruption of the membrane. Most of the activity was discovered in the supernatant after four-time thawing.'

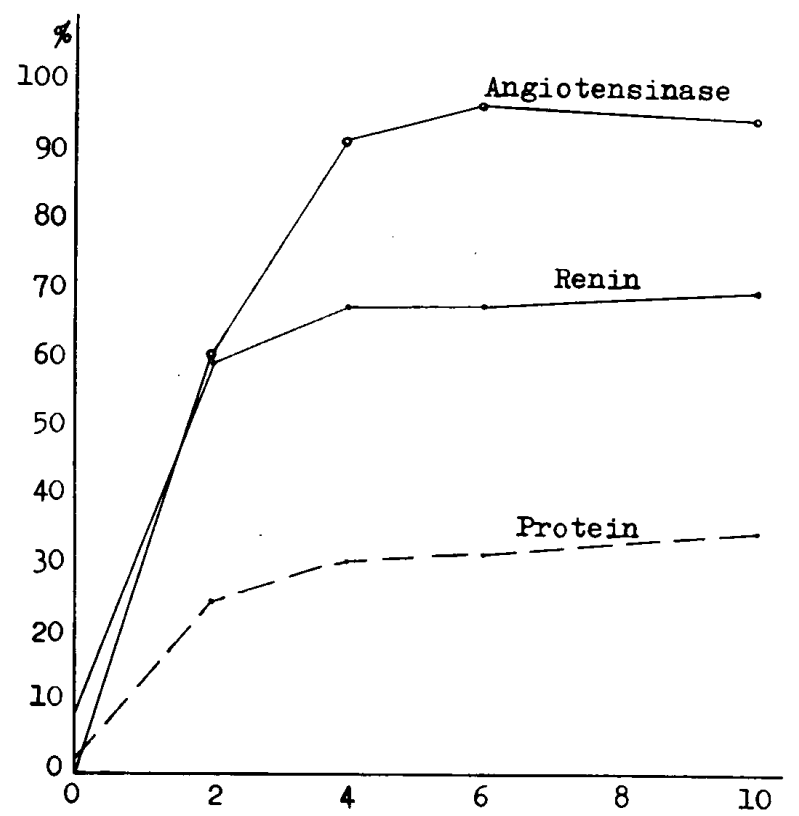

Fig. 1. Release of angiotensinase and renin. Abscissa: Number of times of freezing and thawing; Ordinate: Enzyme activity and protein concentration in the supernatant; values of suspension without centrifugation after ten-time freezing and thawing are taken as 100 per cent.

2. Renin Release from Lysosomal Particles

Release of renin from the subcellular particles in kidney lysosomal fraction by freeze-thaw procedure was already shown by direct pressor method in the previous paper. ${ }^{6}$. It was reinvestigated by using the enzymological method, i.e. angiotensin-forming activity. After the freezethaw treatment on lysosomal fraction as described above, renin activity in the supernatant fluid was measured. One drop of the DFP solution was added to the incubation mixture in this experiment to inhibit the angiotensinase released at the same time. About 70 per cent of the activity was released after four-time thawing, and the remainder did not appear in the supernatant even after ten-time freezing and thawing (Fig. 1). 
3. Separation of Renin and Acid Adenosine Triphosphatase

Renin was evidently separated from acid phosphatase or acid ATPase by gel filtration, whereas separation of the latter two was not so distinct (Fig. 2a). Molecular weights of the three enzyme proteins were roughly estimated according to ANDREws ${ }^{17}$, employing bovine albumin as a standard. The molecular weight of renin was between 40,000 and 50,000, and those of the dephosphorylating enzymes were 90,000 to 100,000 .

Acid ATPase activity was divided into more than three peaks in the elution diagram by DEAE-cellulose column chromatography, while renin showed only one peak (Fig. 3a). Direct pressor potency well corresponded to the enzy- matic renin activity on both Sephadex and DEAE-cellulose (Fig. 2b and Fig. 3b).

\section{Discussion}

It was demonstrated in this paper that rat kidney contains two types of angiotensinase; one is located in lysosomes and the other in microsomes. Lysosomal angiotensinase is active at an acid $\mathrm{pH}$, markedly inhibited by DFP but scarcely by EDTA. On the other hand, the microsomal enzyme is active near neutral $\mathrm{pH}$, inhibited through dialysis against EDTA and activated by calcium ion. It is unaffected by DFP. A slight activity found in mitochondrial and supernatant fractions could be attributed to contamination of lysosomes or microsomes.

As is well known, the kidney is one of the

(a)

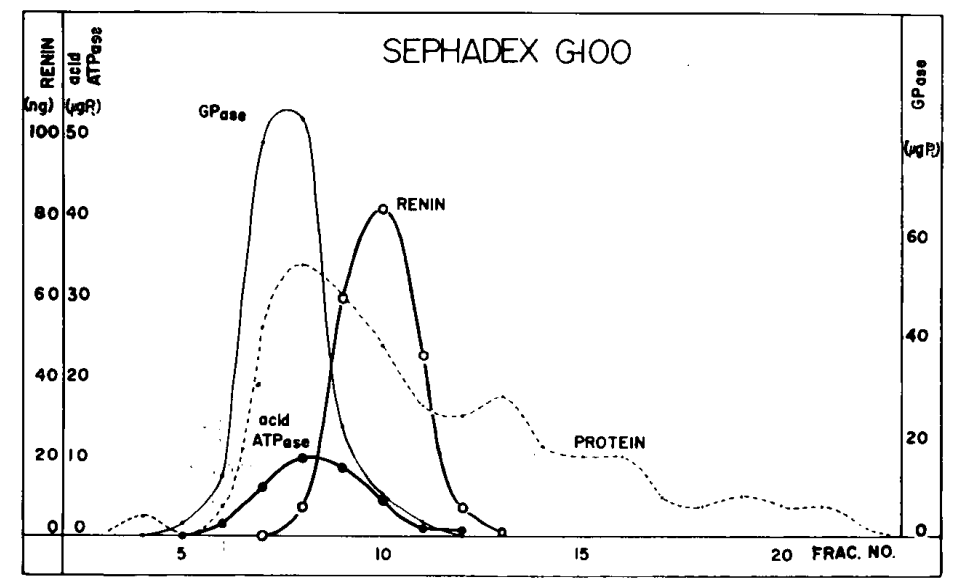

(b)
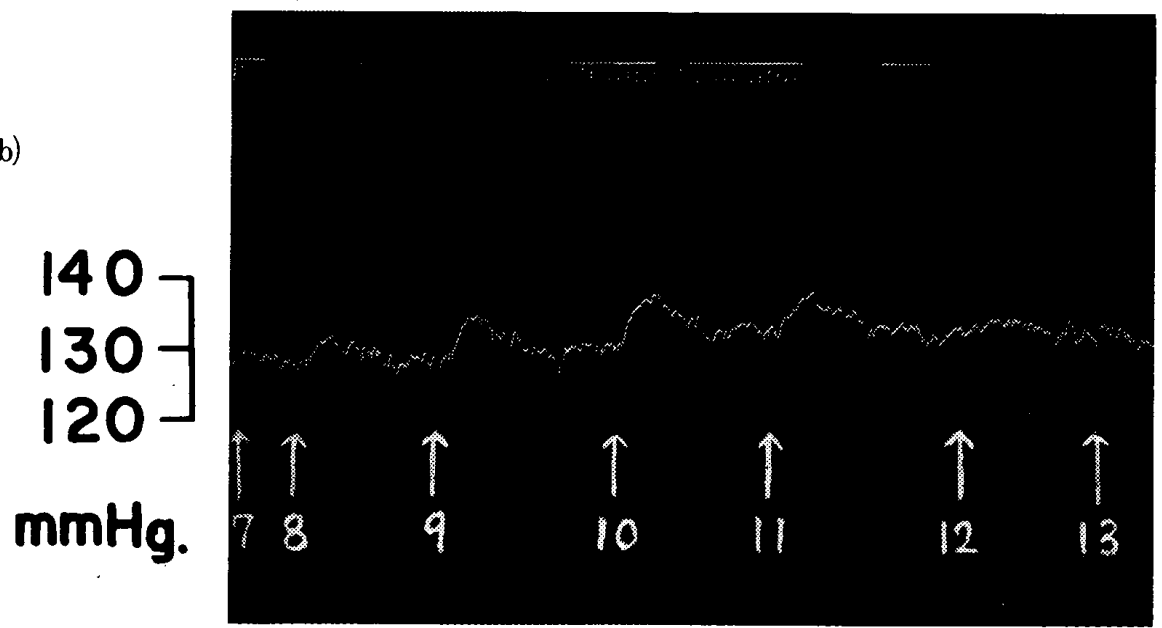

Fig. 2. Sephadex G-100 gel filtration of the content of kidney lysosomal fraction.

a: Enzyme activities of renin, acid adenosine triphosphatase and acid phosphatase,

b: Direct pressor effect of eluates; fraction numbers are shown. 
most angiotensinase-rich organs ${ }^{18}$. Bumpus et al. ${ }^{19}$ suggested an important role played by the kidney in the metabolic fate of angiotensin. They and $\mathrm{HEss}^{20}$ considered an 'arylamidase found in kidney microsomes to be closely related to angiotensinase $\mathrm{A}$ in blood. Our results on the characteristics of microsomal angiotensinase are consistent with their observations. Angiotensinase, however, is not a single enzyme. REGOLI et al. ${ }^{21}$ state that 60 percent of degradation of angiotensin in rat kidney homogenate or in human plasma is due to the activity of an aminopeptidase and 40 per cent to that of a chymotrypsin-like endopeptidase. Although in most reports, so far, determination of angio-. tensinase activity was done near neutral $\mathrm{pH}$, Pickens et al. ${ }^{22}$ found two types of plasma angiotensinase, i.e., one is active at a neutral $\mathrm{pH}$ inhibited by EDTA and the other active at: an acid $\mathrm{pH}$ inhibited by DFP. They also stated. that kidney angiotensinase was partially inhibited by DFP. The latter would necessarily result from the co-existence of the lysosomal and microsomal enzymes. The characteristics

(a)

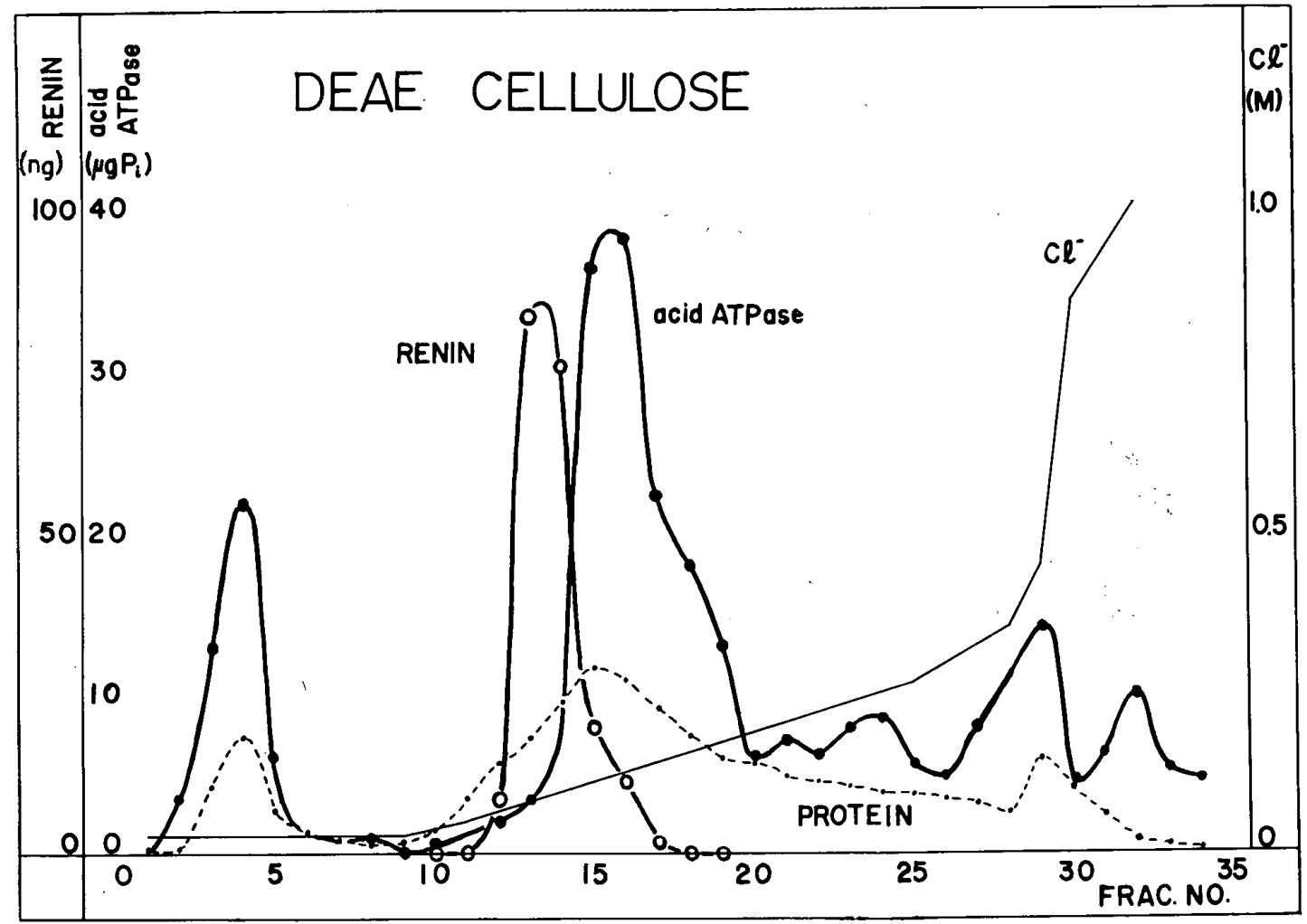

(b)

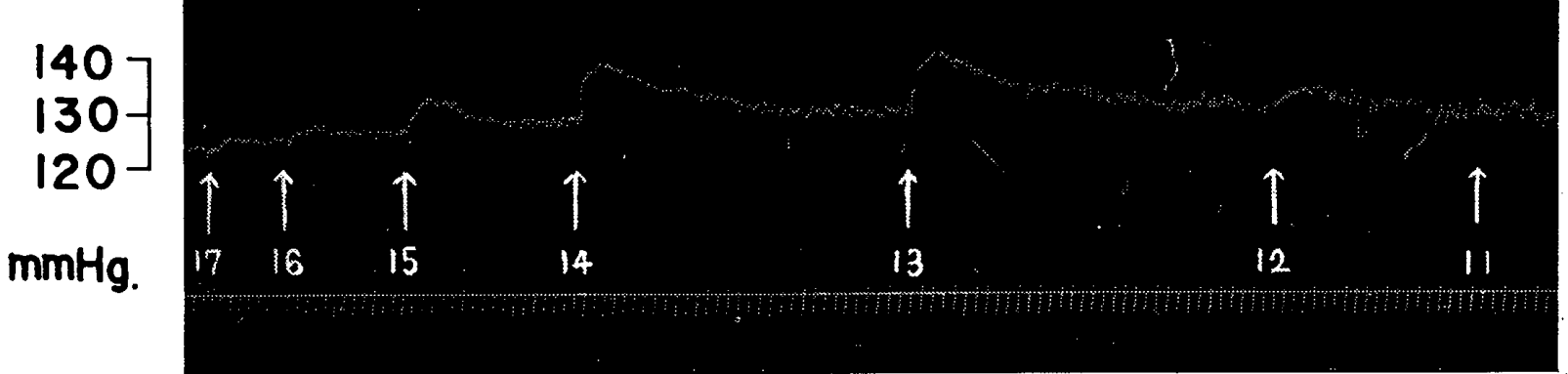

Fig. 3. DEAE-cellulose column chromatography of the content of kidney lysosomal fraction.

a: Enzyme activities of renin and acid adenosine triphosphatase,

b: Direct pressor effect of eluates; fraction numbers are shown. 
of lysosomal angiotensinase of the kidney are so similar to those of plasma acid angiotensinase, that a relationship between the two could be suggested.

The occurrence of cathepsins in lysosomes has been well established since de Duve's discovery $^{1,2,5,23-25}$. SHIBKo and TAPPEL ${ }^{12}$ reported that rat kidney lysosomes contain cathepsin A and cathepsin B. MaHAdevan and TAPPEL ${ }^{26}$ recently found an arylamidase in lysosomes of rat kidney and liver. Therefore, it is possible that some peptidase(s) known in lysosomes participated in degradation of angiotensin. Cathepsin B, C, D, and E are not inhibited by $\mathrm{DFP}^{27-29}$, so that they would be differentiated from lysosomal angiotensinase. Lysosomal arylamidase also seems to be different from the angiotensinase, because kidney lysosomes lose 90 per cent of their arylamidase activity in 24 hours during storage in the absence of a thiol compound, and the arylamidase has a neutral $\mathrm{pH}$ optimum ${ }^{26}$. Although loss of lysosomal angiotensinase activity was found during storage in a deep freezer, it was very slow as compared with that of arylamidase(Table III). However, further investigation is necessary for differentiation or identification of acid angiotensinase.

Table III Inactivation of Angiotensinases DURING STORAGE

\begin{tabular}{ccc}
\hline \hline $\begin{array}{l}\text { Days after } \\
\text { preparation }\end{array}$ & Lysosomal & Microsomal \\
\hline 11 & 215 & 223 \\
53 & 125 & 220 \\
\hline
\end{tabular}

Activity is expressed in nanograms of angiotensin inactivated by $0.1 \mathrm{mg}$ of protein, at $37^{\circ} \mathrm{C}$ for 15 minutes.

Release of renin from the subcellular particles in kidney lysosomal fraction was reconfirmed. HAAS et al. ${ }^{30}$ commented earlier that the yield and specific activity of renin were increased by freezing and thawing the whole kidney up to four times before the extraction. Our observations shown in Fig. 1 well interpret their results at subcellular level: renin was brought to soluble and easily extractable phase from inside of the membrane of the particles and the release was leveled off after four-time freezing and thawing.

Renin was separated from acid ATPase by either Sephadex G-100 gel filtration or DEAE- cellulose column chromatography. It showed only one peak by either procedure. The molecular weight of renin calculated as 40,000 to 50,000 is compatible with those values of hog or human renin estimated by others ${ }^{11,31,32}$. SkEGGS et al. ${ }^{33}$ found four components in hog renin on DEAE-cellulose column chromatography after dialysis at an acid $\mathrm{pH}$, and attributed the uniformity observed by PEART et al.$^{34}$ to an acidification treatment during their purification procedure. Since renin from lysosomal fraction in the present study was never affected by any of such drastic treatment, it is likely that natural renin consist of only one component, and SkEGGS' four components would be rather artificial as they themselves suggested.

At least three components were found in acid ATPase from lysosomal fraction of rat kidney. $\mathrm{KIRA}^{35}$ found recently that acid ATPase in human serum or extracts of various organs was separated into more than two components by DEAE-cellulose column chromatography or gel filtration. The meaning of these isozymes of acid ATPase is still obscure and further study is required.

\section{SUMMARY}

1. Kidney angiotensinases are located in two kinds of subcellular fraction-lysosomal and microsomal. Lysosomal angiotensinase is active at an acid $\mathrm{pH}$ and inhibited by DFP, suggesting a relationship to plasma acid angiotensinase. Most of the activity was released from the particles by freezing and thawing. The microsomal enzyme is active near neutral $\mathrm{pH}$, activated by calcium ion and inhibited by EDTA.

2. About 70 per cent of renin activity was released from the subcellular particles in lysosomal fraction of rat kidney by freeze-thaw method. It revealed only one peak on either Sephadex G-100 gel filtration or DEAE-cellulose column chromatography. The molecular weight of renin was calculated as 40,00050,000

3. At least three components of acid ATPase were found in lysosomal fraction of rat kidney by DEAE-cellulose column chromatography. 


\section{REFERENCES}

1. Ciba Foundation Symposium on Lysosomes, edited by Reuk, A. V. S. And Cameron, M. P.: Little Brown, Boston, 1963.

2. Weissmann, G.: Lysosomes, New Engl. J. Med. 273: $1084 ; 1143,1965$.

3. De Duve, C. and Wattiaux, R.: Functions of Lysosomes, Ann. Rev. Physiol. 28: 453, 1966.

4. The Role of Lysosomes in Pathology, Proc. Roy. Soc. Med. 59: 19, 1966.

5. Weissmann, G.: The Role of Lysosomes in Inflammation and Disease, Ann. Rev. Med. 18: 97, 1967.

6. Ogino, K., Matsunaga, M., Saito, N., Kira, J., Takayasu, M., and Ono, K. : Renin and Acid Adenosine Triphosphatase as Lysosomal Enzymes, Jap. Circul. J. 31 : 1, 1967.

7. Kira, J., Saito, N., Matsunaga, M., Ogino, K., and Takayasu, M.: Hemoconcentrating Substance and Vascular Permeability Factor from Rat Kidney Lysosomes, Jap. Circul. J. 32: 1, 1968.

8. Matsunaga, M.: Some Aspects on the Mechanisms in the Development of Hypertension by Renin, Saishin Igaku 22: 900, 1967. (in Japanese)

9. Takayasu, M. and Ogino, K.: Essential Hypertension from the Viewpoint of Enzyme Anomaly, Sogo Rinsho 16: 9, 1967. (in Japanese).

10. Takayasu, M., Ogino, K., Matsunaga, M., Saito, N., AND KIra, J.: Clinical Medicine and Lysosomes, Nippon Rinsho. 25: 2363; 2563, 1967. (in Japanese).

11. Peart, W. S.: The Renin-Angiotensin System, Pharmacol. Rev. 17: 143, 1965.

12. Shibko, S. And Tappel, A. L.: Rat Kidney Lysosomes: Isolation and Properties, Biochem. J. 95: $731,1965$.

13. Lowry, O. H., Rosenbrough, N. J., Farr, A. L., and Randall, R. J.: Protein Measurement with the Folin Phenol Reagent, J. Biol. Chem. 193: 265, 1951.

14. Nakamura, M.: Colorimetric Determination of Phosphorus, Nippon Nogei Kagakukaishi. 24: 1, 1950. (in Japanese)

15. Peterson, E. A. and Sober, H. A.: Column Chromatography of Proteins: Substituted Celluloses, Methods in Enzymology. 5: 3, 1962, Academic Press, New York.

16. Bock, R. M. And Nan-sing Ling: Devices for Gradient Elution in Chromatography, Analyt. Chem. 26: 1543, 1954.

17. ANDREWS, P.: Estimation of the Molecular Weights of Proteins by Sephadex Gel-Filtration, Biochem. J. 91 : 222, 1964.

18. Page, I. H. And Bumpus, F. M.: Angiotensin, Physiol. Rev. $41: 331,1961$.

19. Bumpus, F. M., Smeby, R. R., Page, I.H., ANd Khairallah, P. A.: Distribution and Metabolic Fate of Angiotensin II and Various Derivatives,
Canad. Med. Assoc.J. 90: 190, 1964.

20. Hess, R.: Arylamidase Activity Related to Angiotensinase, Biochim. Biophys. Acta. 99: 316, 1965.

21. Regoli, D., Riniker, B., and Brunner, H.: The Enzymatic Degradation of Various Angiotensin II Derivatives by Serum, Plasma or Kidney Homogenate, Biochem. Pharmacol. 12: 637, 1963.

22. Pickens, P. T.; Bumpus, F. M., Lloyd, A. M., SmeBY, R. R., AND PAGE, I. H.: Measurement of Renin Activity in Humạn Plasma, Circul. Res. 17: 438, 1965.

23. Gianetro; R. and De-Duve, C. : Tissue Fractionation Studies 4. Comparative Study of the Binding of Acid Phosphatase, $\beta$-Glücuronidase and Cathesin by Rat Liver Particles, Biochem. J. 59: 433, 1955.

24. De Duve, C.: Lysosomes, A New Group of Cytoplasmic Particles, in Subcellular Particles, edited by Hayashi, T., Ronald Press, New York, p. 128, 1959.

25. De Duve, C., Wattiaux, R., and Baudhuin, P.: Distribution of Enzymes in Animal Tissues, $A d$ vance in Enzymology 24: 291, 1962.

26. Mahadevan, S. And Tappel, A. L.: Arylamidases of Rat Liver and Kidney, J. Biol. Chem. 242: 2369, 1967.

27. Smith, E. L.: Peptide Bond Cleavage (Survey), The Enzymes 4: 1, 1960., Academic Press, New York.

28. Press, E. M., Porter, R. R., and Cebra, J.: The Isolation and Properties of a Proteolytic Enzyme, Cathepsin D, from Bovine Spleen, Biochem. J. 74: $501,1960$.

29. Lapresle, C. and Webb, T.: The Purification and Properties of a Proteolytic Enzyme, Rabbit Cathepsin E, and Further Studies on Rabbit Cathepsin D, Biochem. J. 84: 455, 1962.

30. Haas, E., Lamfrom, H., and Goldblatt, H.: A Simple Method for the Extraction and Partial Purification of Renin, Arch. Biochem. Biophys. 48: 256, 1954.

31. Kemp, E. And Rubin, I.: Molecular Weight of Renin Determined by Sephadex Gel-Filtration, Acta Chem. Scand. 18: 2403, 1964.

32. Warren, B. and Dolinsky, M. : Molecular Weight of Human Renin, Proc. Soc. Exper. Biol. Med. 123: $911,1966$.

33. Skeggs, L. T., Lentz, K. E., Khan, J. R., And Hochstrasser, H. : Studies on the Preparation and Properties of Renin, Circul. Res. 21 : Suppl. II-91, 1967.

34. Peart, W. S., Lloyd, A. M., Thatcher, G. N., Lever, A. F., Payne, N., and Stone, N. : Purification of Pig Renin, Biochem. J. 99: 708, 1966.

35. Kira, J.: Clinical and Experimental Studies on Acid Adenosine Triphosphatase, with Special Reference to Lysosomes and Isozyme, Jap. Circul. J. (to be published) 